\title{
Effects of the mycelial extract of cultured Cordyceps sinensis on in vivo hepatic energy metabolism and blood flow in dietary hypoferric anaemic mice
}

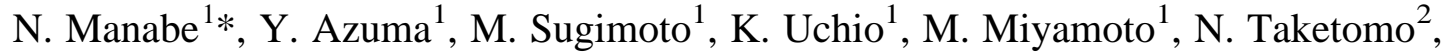 \\ H. Tsuchita ${ }^{3}$ and H. Miyamoto ${ }^{1}$ \\ ${ }^{1}$ Unit of Anatomy and Cell Biology, Department of Animal Sciences, Kyoto University, Kyoto 606-8502, Japan \\ ${ }^{2}$ Meiji Institute of Health Science, Meiji Milk Products Co. Ltd, Odawara 250-0862, Japan \\ ${ }^{3}$ Nutrition Science Institute, Meiji Milk Products Co. Ltd, Tokyo 189-8530, Japan
}

(Received 4 January 1999 - Revised 21 July 1999 - Accepted 17 August 1999)

\begin{abstract}
The beneficial effects of a traditional Chinese medicine, Cordyceps sinensis (Cs), on mice with hypoferric anaemia were evaluated by NMR spectroscopy. Experimental hypoferric anaemia was induced in mice by feeding with an Fe-free diet for 6 weeks. They were then given extract from cultured Cs ( $200 \mathrm{mg} / \mathrm{kg}$ body weight daily, orally) and were placed on an Fe-containing recovery diet (35 mg Fe/kg diet) for 4 weeks. In vivo ${ }^{31} \mathrm{P}$ and ${ }^{2} \mathrm{H}$ NMR spectra acquired noninvasively and quantitatively at weekly intervals were used to evaluate hepatic energy metabolism and blood flow in the mice. During the 4-week Cs-extract treatment, consistent increases were observed in liver $\beta$-ATP : inorganic phosphate value by liver ${ }^{31} \mathrm{P}$ NMR spectroscopy, representing the high energy state, and in blood-flow rate as determined by ${ }^{2} \mathrm{H}$ NMR spectroscopy of deuterated water $\left(\mathrm{D}_{2} \mathrm{O}\right)$ uptake after intravenous injection of $\mathrm{D}_{2} \mathrm{O}$. The haematological variables (the packed cell volume and the haemoglobin level) and the hepatic intracellular $\mathrm{pH}$, which was determined from the NMR chemical shift difference between the inorganic phosphate peak and the $\alpha$-phosphate peak of ATP, were not significantly different between Cs-extract-treated and control mice. As blood flow and energy metabolism are thought to be linked, the Cs-extract-increased hepatic energy metabolism in the dietary hypoferric anaemic mice was concluded to be due to increased hepatic blood flow.
\end{abstract}

Nuclear magnetic resonance: Energy metabolism: Chinese medicine

Cordyceps sinensis (Cs) is a parasitic fungus found on larvae of Lepidoptera. The fruiting bodies of Cs together with the larvae have been used for a long time in traditional Chinese medicine. Various pharmacological effects of this medicine, a hot-water extract of fruiting bodies and mycelia of $\mathrm{Cs}$, on human subjects and animals both in vitro and in vivo have been reported (Chatterjee et al. 1957; Furuya et al. 1983; Hamada, 1991; Yoshida et al. 1992; Tsunoo et al. 1995; Manabe et al. 1996). These include a cure for tuberculosis and a restorative action after various diseases (Chatterjee et al. 1957), in vivo inotropic effects on the left atrium (Furuya et al. 1983) and anti-tumour activities (Hamada, 1991; Yoshida et al. 1992). Previous in vitro pharmacological studies have shown that mycelial extract of cultured Cs (Cs extract) produces non-purinergic and nonadrenergic inhibition of tracheal twitch contraction and relaxes persistent contraction of the trachea and the aorta, and the Cs extract was more effective in reducing tracheal activities than other traditional Chinese medicines (Tsunoo et al. 1995). Previously, in vivo ${ }^{31} \mathrm{P} \mathrm{NMR}$ spectroscopic analyses have revealed a consistent increase in the liver $\beta$-ATP : inorganic phosphate $(\mathrm{Pi})$ ratio, which represents the high energy state in the liver, in Cs-extract-treated mice (Manabe et al. 1996). The liver intracellular $\mathrm{pH}$ was not significantly different between Cs-extract-treated and control mice, and no histopathological changes, steatosis, necrosis, inflammation or fibrosis, were observed in the liver specimens from Cs-extract-treated mice. These clinical effects of, and experimental findings about, this traditional Chinese medicine indicated that the Cs extract may increase blood flow in the liver and other organs. The present study was performed to confirm the efficacy, i.e. ability to increase hepatic blood flow, of $\mathrm{Cs}$ in anaemia. We evaluated the effects of Cs-extract treatment on hepatic blood flow and energy metabolism in mice with dietary hypoferric anaemia. In vivo ${ }^{31} \mathrm{P} \mathrm{NMR}$ analysis of the liver was performed on 
Fe-deficient anaemic mice administered Cs extract. As blood flow and energy metabolism are thought to be linked (Okunieff et al. 1988; Tozer et al. 1990), ${ }^{2} \mathrm{H}$ NMR spectroscopy of deuterated water $\left(\mathrm{D}_{2} \mathrm{O}\right)$ uptake after intravenous injection of $\mathrm{D}_{2} \mathrm{O}$ was used to measure hepatic blood flow in the anaemic mice treated with Cs extract (Mattiello \& Evelhoch, 1991; Zhao et al. 1995). The in vivo structurebiological assessment techniques for energy metabolism and blood flow are useful not only for pharmaceutical and toxicological sciences but also for nutritional sciences.

\section{Materials and methods}

\section{Cs-extract preparation}

Hot-water extract from cultured Cs (Cs extract) was prepared according to the method described previously (Tsunoo et al. 1995; Manabe et al. 1996). Briefly, the Cs strain SMIH8819 was isolated at the Sanming Mycological Institute (Sanming, China). This strain was maintained on malt extract agar slants composed of (g/l): 20 malt extract, 1 peptone and 20 glucose, and then cultured in fermentation medium $(\mathrm{g} / \mathrm{l}$ : sucrose 40 , $\mathrm{K}_{2} \mathrm{HPO}_{4} 4$, asparagine $4,\left(\mathrm{NH}_{4}\right)_{2} \mathrm{HPO}_{4} 2, \mathrm{MgSO}_{4} .7 \mathrm{H}_{2} \mathrm{O} 2$, $\mathrm{CaCO}_{3} 0 \cdot 25, \mathrm{CaCl}_{2} \mathrm{O} \cdot 1$ and yeast extract 4$)$. The $\mathrm{pH}$ of the medium was adjusted to $5 \cdot 5$ before sterilization. During fermentation, the medium was aerated at a rate of 30 litres/ min. After fermentation, the mycelia of cultured Cs were extracted with hot water $\left(90^{\circ}\right)$ for $2 \mathrm{~h}$, and then the extract was filtered through a membrane filter $(0 \cdot 22 \mu \mathrm{m})$ and lyophilized.

\section{Experimental protocol}

Male ICR mice purchased from SLC (Shizuoka, Japan) weighing an average of 13.9 (SE 0.8 ) $\mathrm{g}$ at the beginning of the experiment were used at 3 weeks of age. During the experiment, the mice were given free access to tap water in an air-conditioned room $\left(22 \pm 2^{\circ}\right.$, relative humidity $\left.55 \pm 5 \%\right)$ under a controlled $12 \mathrm{~h}$ light-dark cycle. All animals received humane care as outlined in the Guide for the Care and Use of Laboratory Animals (Japanese Animal Care Committee, 1981). The mice were given an Fe-free diet (Table 1) for 6 weeks to induce Fe-deficiency anaemia as described previously (Tsuchita et al. 1991). Normal mice were given a basal diet (Table 1; containing $35 \mathrm{mg}$ ferric citrate/kg) (Tsuchita et al. 1991).

Twelve mice with dietary hypoferric anaemia were divided into two groups, vehicle control and Cs-extract-treated groups, with six mice in each group. Twelve normal mice were also divided into two groups, vehicle control and Cs-extract-treated groups, with six mice in each group. The anaemic and normal Cs-extract-treated groups received Cs extract dissolved in distilled water, orally, at a dose of $200 \mathrm{mg} / \mathrm{kg}$ per $\mathrm{d}$ in a volume of $5 \mathrm{ml} / \mathrm{kg}$ for 4 weeks. The anaemic and normal vehicle control groups were given distilled water orally $(5 \mathrm{ml} / \mathrm{kg}$ per d) for 4 weeks. During the 4 weeks of Cs-extract treatment, all animals were given a recovery diet (Table 1; containing $35 \mathrm{mg}$ ferric chloride $/ \mathrm{kg}$ ) (Tsuchita et al. 1991).

\section{Histological and haematological analyses}

As described earlier, six mice in each group (normal and anaemic groups) were killed under diethyl ether anaesthesia at the beginning, 3 weeks after commencement of the experiment and before Cs-extract treatment. After the final NMR experiment, the remaining animals (six mice in each group) were killed under diethyl ether anaesthesia. The livers were removed, weighed and fixed in $100 \mathrm{ml} / \mathrm{l}$ buffered

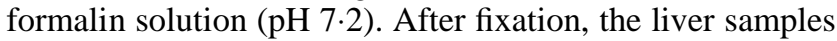
were embedded in paraffin and cut into sections $3 \mu \mathrm{m}$ thick which were then stained with haematoxylin and eosin by routine methods. The liver histopathology was examined by light microscopy and scored as indicated by Takahashi et al. (1990).

During Cs-extract treatment, collection of blood samples from the tail vein was repeated at intervals of 1 week, and packed cell volumes and haemoglobin levels were measured by conventional methods.

\section{NMR measurements}

${ }^{31} \mathrm{P},{ }^{1} \mathrm{H}$ and ${ }^{2} \mathrm{H}$ NMR spectra were acquired on a JNMalpha-400 FT-NMR spectrometer (JEOL, Tokyo, Japan). All NMR experiments were repeated at 1-week intervals during $\mathrm{Cs}$ administration and were performed at $25 \pm 1^{\circ}$. The

Table 1. Composition of mineral mixture ( $\mathrm{g} / \mathrm{kg}$ mixture) contained in the basal, recovery and iron-free diets fed to mice*

\begin{tabular}{|c|c|c|c|}
\hline Minerals & Basal diet & Recovery diet & Fe-free diet \\
\hline $\mathrm{CaHPO}_{4}$ & $500 \cdot 0$ & $500 \cdot 0$ & $500 \cdot 00$ \\
\hline $\mathrm{NaCl}$ & 74.0 & 74.0 & 74.0 \\
\hline Tripotassium citrate monohydrate & $220 \cdot 0$ & $220 \cdot 0$ & $220 \cdot 0$ \\
\hline $\mathrm{K}_{2} \mathrm{SO}_{4}$ & $52 \cdot 0$ & $52 \cdot 0$ & $52 \cdot 0$ \\
\hline $\mathrm{MgO}$ & $24 \cdot 0$ & $24 \cdot 0$ & $24 \cdot 0$ \\
\hline $\mathrm{MnCO}_{3}$ & 3.5 & 3.5 & 3.5 \\
\hline $\mathrm{ZnCO}_{3}$ & 1.6 & 1.6 & 1.6 \\
\hline $\mathrm{CuCO}_{3}$ & 0.3 & 0.3 & 0.3 \\
\hline $\mathrm{KIO}_{3}$ & 0.01 & 0.01 & 0.01 \\
\hline $\mathrm{Na}_{2} \mathrm{SeO}_{3} .5 \mathrm{H}_{2} \mathrm{O}$ & 0.01 & 0.01 & 0.01 \\
\hline $\mathrm{CrK}\left(\mathrm{SO}_{4}\right)_{2} \cdot 12 \mathrm{H}_{2} \mathrm{O}$ & 0.55 & 0.55 & 0.55 \\
\hline Ferric citrate & 5.63 & - & - \\
\hline $\mathrm{FeCl}_{3} \cdot 6 \mathrm{H}_{2} \mathrm{O}$ & - & 4.84 & - \\
\hline
\end{tabular}

* Diets contained the following ingredients $(\mathrm{g} / \mathrm{kg})$ : casein 200, DL-methionine 3, maize starch 350, sucrose 300 , cellulose powder 50 , soyabean oil 50 , vitamin mixture 10 , choline bitartrate 2 and mineral mixture 35 . 
NMR spectrometer was equipped with a vertical 9.20 Tesla, $89 \mathrm{~mm}$ bore (inside gradient) superconducting magnet (Oxford Instruments, Bedford, MA, USA). During NMR examination, each mouse was anaesthetized by intraperitoneal injection of sodium pentobarbital $(50 \mathrm{mg} / \mathrm{kg})$, immobilized with surgical tape on a probe-bed, and maintained in a probe-chamber at a controlled air temperature of $25 \pm 1^{\circ}$. As previously reported (Manabe et al. 1996), ${ }^{31} \mathrm{P}$ NMR was performed according to a modification of the method of Takahashi et al. (1990) to obtain in vivo ${ }^{31} \mathrm{P}$ NMR spectra of the steady-state livers in intact animals. Briefly, the mice were mounted on a surface coil probe (two-turns, $20 \mathrm{~mm}$ in diameter; JEOL) which was tuned to ${ }^{31} \mathrm{P}$ at $161.7 \mathrm{MHz}$ used in conjunction with a ferrite screen composed of strips of computer magnetic tape (Scotch 700; Three M Co., St Louis, MO, USA) to eliminate ${ }^{31} \mathrm{P}$ NMR signals arising from superficial muscles (Geoffrion et al. 1988). Field homogeneity was controlled by adjusting shim parameters using a water ${ }^{1} \mathrm{H}$ signal derived from the liver sample. Acquisition conditions were set as follows to obtain fully relaxed signals: pulse width, $20 \mu \mathrm{s}$; pulse repetition time, $3.0 \mathrm{~s} ; 200$ scans. Thus, it took $10 \mathrm{~min}$ for each measurement. After exponential multiplication, the accumulated free induction decays were subjected to Fourier transformation. Individual spectral peak areas were calculated by computer integration with JEOL software, and the creatine phosphate peak was used as an internal reference $(0 \mathrm{ppm})$. The relative amount of each compound was converted to absolute concentration by comparison with the data of an external reference (20 mM-methylene diphosphonate in water) in a spherical bulb. The relative ATP levels were obtained by taking the ratio $\beta$-phosphate peak of ATP ( $\beta$-ATP): reference peak (Azuma et al. 1994), and then the $\beta$-ATP : Pi peak area ratio was calculated to evaluate in vivo liver energy metabolism. The intracellular $\mathrm{pH}$ was determined from the chemical shift difference between the Pi peak and the $\alpha$-phosphate peak of ATP (Malloy et al. 1986).

In vivo ${ }^{2} \mathrm{H}$ and ${ }^{1} \mathrm{H}$ NMR spectra of the livers were obtained by modification of the method of Zhao et al. (1995). Briefly, the ${ }^{2} \mathrm{H}$ and ${ }^{1} \mathrm{H}$ signals were also detected with a coil probe. Spectra were acquired under optimized signal-to-noise conditions where a repetition time : $\mathrm{T}_{1}$ value of 0.93 was used to acquire both ${ }^{2} \mathrm{H}$ and ${ }^{1} \mathrm{H}$ spectra. ${ }^{2} \mathrm{H}$ spectra were acquired with a $60^{\circ}$ flip angle and $0.25 \mathrm{~s}$ repetition time (Mattiello \& Evelhoch, 1991). For blood flow measurement, $100 \mu \mathrm{l} /$ mouse of $9 \mathrm{~g} \mathrm{NaCl} / 1$ in $\mathrm{D}_{2} \mathrm{O}$ was injected into the tail vein via a catheter. Time domain data $(2 \times 256$ points $)$ were averaged into ninety consecutive $4 \mathrm{~s}$ time blocks. Relative volume average blood flow values were calculated by computer integration with JEOL software using the $\mathrm{D}_{2} \mathrm{O}$ uptake integral approach as described by Mattiello \& Evelhoch, (1991). Blood flow rates are expressed as a percentage of the mean value for normal controls on day 0 ( 0 week).

\section{Statistical analysis of data}

The significance of differences between Cs-extract-treated and vehicle control mice was assessed by Student's paired $t$ test carried out with the StatView IV program (J4.5, 95.8.14; Abacus Concepts Inc., Berkeley, CA, USA) using a Macintosh computer. Differences at a probability of $P<$ 0.05 were considered significant. All data are shown as means with their standard errors.

\section{Results \\ Body and liver weight}

As summarized in Table 2, there were no significant differences in body weight, liver weight or relative liver weight (liver weight/body weight $\times 100$ ) between vehicle control and Cs-extract-treated normal or anaemic mice.

\section{Haematology and liver histopathology}

As shown in Table 3, severe Fe-deficiency anaemia was induced by feeding with the Fe-free diet for 6 weeks. During the period of feeding with the Fe-free diet, significant decreases $(P<0.01$; more than $50 \%$ decrease $)$ were observed

Table 2. Changes in body weight, liver weight and relative liver weight in normal and anaemic mice administered vehicle or an extract from Cordyceps sinensis (Cs) for 4 weeks*

(Mean values with their standard errors for six mice)

\begin{tabular}{|c|c|c|c|c|c|c|c|c|c|c|c|}
\hline \multirow[b]{2}{*}{ Variable } & \multirow{2}{*}{$\begin{array}{c}\text { Time (weeks) } \ldots \\
\text { Group }\end{array}$} & \multicolumn{2}{|c|}{-6} & \multicolumn{2}{|c|}{-3} & \multicolumn{2}{|c|}{0} & \multicolumn{2}{|c|}{2} & \multicolumn{2}{|c|}{4} \\
\hline & & Mean & SE & Mean & SE & Mean & SE & Mean & SE & Mean & SE \\
\hline \multirow[t]{2}{*}{ Body weight (g) } & $\begin{array}{l}\text { Normal, vehicle } \\
\text { Normal, Cs extract }\end{array}$ & 13.9 & $0 \cdot 8$ & 30.9 & 1.4 & 35.4 & 0.5 & $\begin{array}{l}36 \cdot 3 \\
36 \cdot 8\end{array}$ & $\begin{array}{l}0.5 \\
1.0\end{array}$ & $\begin{array}{l}37 \cdot 2 \\
37 \cdot 3\end{array}$ & $\begin{array}{l}1.3 \\
1.0\end{array}$ \\
\hline & $\begin{array}{l}\text { Anaemic, vehicle } \\
\text { Anaemic, Cs extract }\end{array}$ & & & $29 \cdot 0$ & $1 \cdot 2$ & $34 \cdot 7$ & 1.0 & $\begin{array}{l}35 \cdot 8 \\
35 \cdot 6\end{array}$ & $\begin{array}{l}0.7 \\
0.7\end{array}$ & $\begin{array}{l}37 \cdot 3 \\
37 \cdot 2\end{array}$ & $\begin{array}{l}0.9 \\
0.9\end{array}$ \\
\hline \multirow[t]{2}{*}{ Liver weight (g) } & $\begin{array}{l}\text { Normal, vehicle } \\
\text { Normal, Cs extract }\end{array}$ & 0.61 & 0.05 & 1.52 & 0.08 & 1.68 & $0 \cdot 10$ & & & $\begin{array}{l}1.75 \\
1.80\end{array}$ & $\begin{array}{l}0.07 \\
0.04\end{array}$ \\
\hline & $\begin{array}{l}\text { Anaemic, vehicle } \\
\text { Anaemic, Cs extract }\end{array}$ & & & 1.44 & 0.09 & 1.63 & 0.13 & & & $\begin{array}{l}1.77 \\
1.80\end{array}$ & $\begin{array}{l}0.05 \\
0.04\end{array}$ \\
\hline \multirow[t]{2}{*}{ Relative liver weight (\%) } & $\begin{array}{l}\text { Normal, vehicle } \\
\text { Normal, Cs extract }\end{array}$ & 4.51 & 0.64 & 4.35 & 0.26 & 4.62 & 0.27 & & & $\begin{array}{l}4.71 \\
4.83\end{array}$ & $\begin{array}{l}0.03 \\
0.05\end{array}$ \\
\hline & $\begin{array}{l}\text { Anaemic, vehicle } \\
\text { Anaemic, Cs extract }\end{array}$ & & & $4 \cdot 10$ & 0.23 & 4.54 & 0.35 & & & $\begin{array}{l}4 \cdot 74 \\
4 \cdot 84\end{array}$ & $\begin{array}{l}0.08 \\
0.09\end{array}$ \\
\hline
\end{tabular}

\footnotetext{
${ }^{*}$ For details of diets, extracts and procedures, see Table 1 and pp. 198-199.
} 
Table 3. Changes in packed cell volume and haemoglobin levels in normal and anaemic mice administered vehicle or an extract from Cordyceps sinensis (Cs) for 4 weeks*

(Mean values with their standard errors for six mice)

\begin{tabular}{|c|c|c|c|c|c|c|c|c|c|c|c|}
\hline \multirow[b]{2}{*}{ Variable } & \multirow{2}{*}{$\begin{array}{c}\text { Time (weeks) } \ldots \\
\text { Group }\end{array}$} & \multicolumn{2}{|c|}{-6} & \multicolumn{2}{|c|}{-3} & \multicolumn{2}{|c|}{0} & \multicolumn{2}{|c|}{2} & \multicolumn{2}{|c|}{4} \\
\hline & & Mean & SE & Mean & SE & Mean & SE & Mean & SE & Mean & SE \\
\hline \multirow[t]{2}{*}{ Packed cell volume (\%) } & $\begin{array}{l}\text { Normal, vehicle } \\
\text { Normal, Cs extract }\end{array}$ & 13.6 & 0.9 & $13 \cdot 3^{a}$ & 1.0 & $13 \cdot 3^{a}$ & 1.2 & $\begin{array}{l}13 \cdot 9^{a} \\
13 \cdot 7^{a}\end{array}$ & $\begin{array}{l}1.1 \\
1.5\end{array}$ & $\begin{array}{l}13 \cdot 8^{a} \\
13 \cdot 9^{a}\end{array}$ & $\begin{array}{l}1.1 \\
1.4\end{array}$ \\
\hline & $\begin{array}{l}\text { Anaemic, vehicle } \\
\text { Anaemic, Cs extract }\end{array}$ & & & $6 \cdot 0^{\mathrm{b}}$ & $0 \cdot 8$ & $4 \cdot 5^{b}$ & $0 \cdot 7$ & $\begin{array}{l}12 \cdot 7^{\mathrm{a}} \\
13 \cdot 1^{\mathrm{a}}\end{array}$ & $\begin{array}{l}0.8 \\
0.9\end{array}$ & $\begin{array}{l}13 \cdot 7^{\mathrm{a}} \\
13 \cdot 2^{\mathrm{a}}\end{array}$ & $\begin{array}{l}0.8 \\
1.0\end{array}$ \\
\hline \multirow[t]{2}{*}{ Haemoglobin $(\mathrm{g} / \mathrm{l})$} & $\begin{array}{l}\text { Normal, vehicle } \\
\text { Normal, Cs extract }\end{array}$ & 525 & 36 & $527^{a}$ & 47 & $518^{a}$ & 44 & $\begin{array}{l}527^{\mathrm{a}} \\
526^{\mathrm{a}}\end{array}$ & $\begin{array}{l}53 \\
38\end{array}$ & $\begin{array}{l}529^{a} \\
533^{a}\end{array}$ & $\begin{array}{l}33 \\
32\end{array}$ \\
\hline & $\begin{array}{l}\text { Anaemic, vehicle } \\
\text { Anaemic, Cs extract }\end{array}$ & & & $211^{\mathrm{b}}$ & 24 & $174^{\mathrm{b}}$ & 25 & $\begin{array}{l}490^{\mathrm{a}} \\
505^{\mathrm{a}}\end{array}$ & $\begin{array}{l}31 \\
35\end{array}$ & $\begin{array}{l}526^{a} \\
528^{a}\end{array}$ & $\begin{array}{l}33 \\
25\end{array}$ \\
\hline
\end{tabular}

${ }^{a, b}$ Mean values within a row not sharing a common superscript letter were significantly different: $P<0.01$.

${ }^{*}$ For details of diets, extract and procedures, see Table 1 and pp. 198-199.

(a)

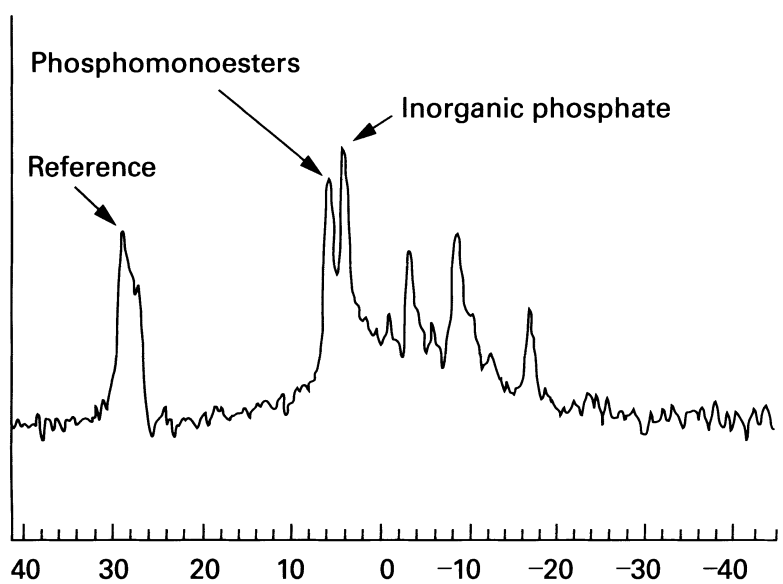

(c)

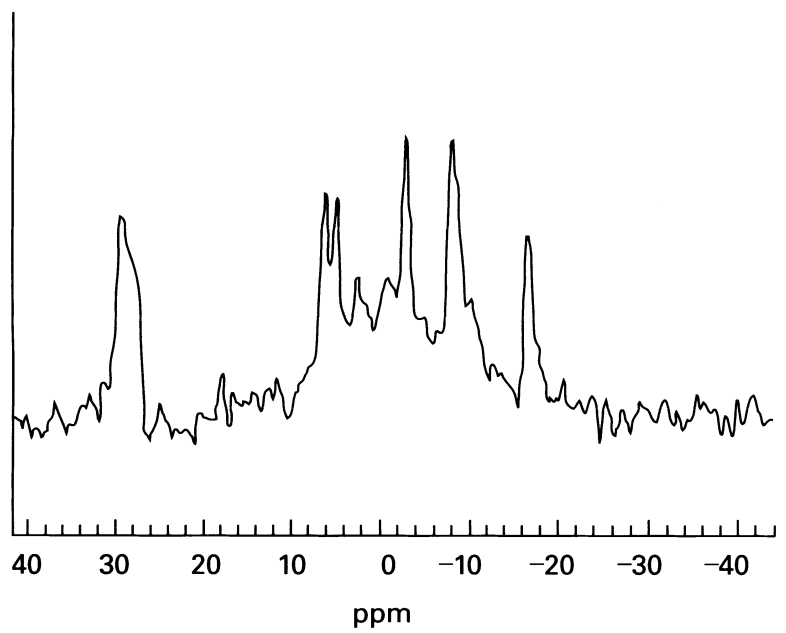

(b)

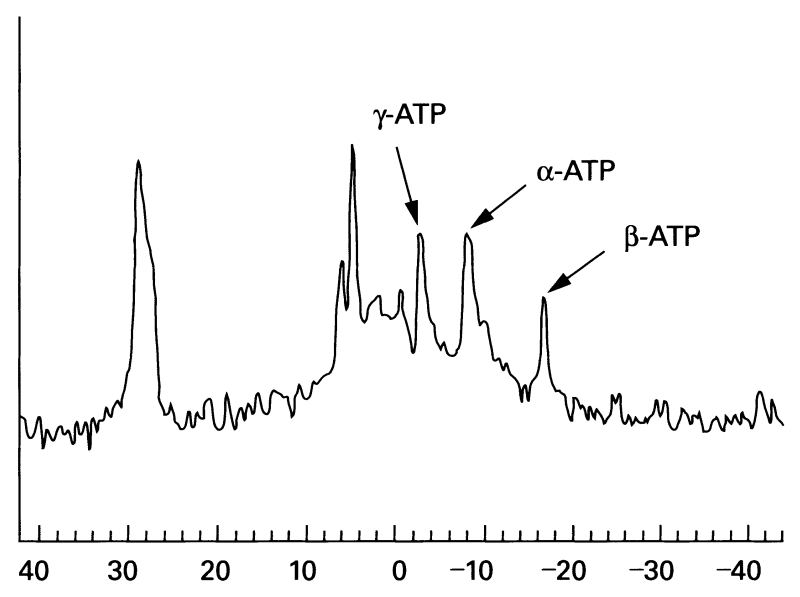

(d)

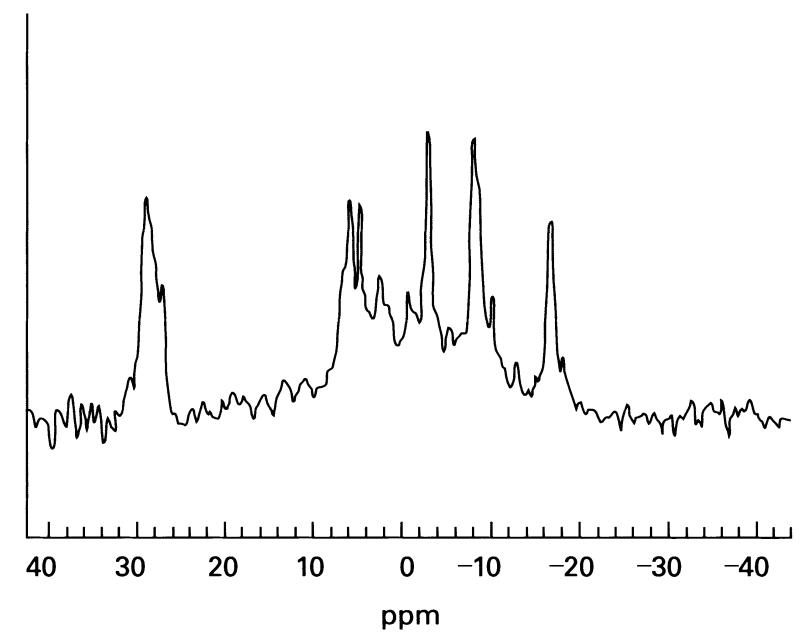

Fig. 1. Representative in vivo ${ }^{31} \mathrm{P}$ NMR spectra obtained from normal ( $a$ and $c$ ) and anaemic ( $b$ and $\left.d\right)$ mice administered vehicle (a and $b$ ) or an extract from Cordyceps sinensis (c and d) at 4 weeks after the initial administration. The creatine phosphate peak was used as the internal reference $(0 \mathrm{ppm})$, and prominent peaks observed were phosphomonoester, inorganic phosphate and nucleotide triphosphate (mainly $\gamma$-ATP, $\alpha$-ATP and $\beta$-ATP). The $\gamma$-ATP and $\alpha$-ATP signals may contain contributions from $\beta$ - and $\alpha$-ADP respectively. The signal corresponding to $\beta$-ATP that has no overlap with the other phosphate signals was used to quantify ATP, and its spectral peak area was calculated by computer integration. Increases in hepatic ATP level and decreases in the inorganic phosphate levels were demonstrated in both normal and anaemic mice treated with Cordyceps sinensis extract. 
in both packed cell volumes and blood haemoglobin levels. During Cs-extract administration, a recovery diet was given to the anaemic mice. The Cs extract had no effect on packed cell volumes or blood haemoglobin levels in normal or anaemic mice.

During the experiment, conventional histopathological evaluation of the liver was performed. No liver specimens obtained from either Cs-extract-treated or vehicle control mice in either normal or anaemic groups showed steatosis, necrosis, inflammation or fibrosis (results not shown).

\section{${ }^{31}$ P NMR spectroscopy for liver ATP measurement}

Representative examples of the in vivo liver ${ }^{31} \mathrm{P} \mathrm{NMR}$ spectra acquired from vehicle control and Cs-extract-treated groups of both normal and anaemic mice at 4 weeks after the initial administration (final NMR measurement) are shown in Fig. 1. Peak assignments are given in the legend.

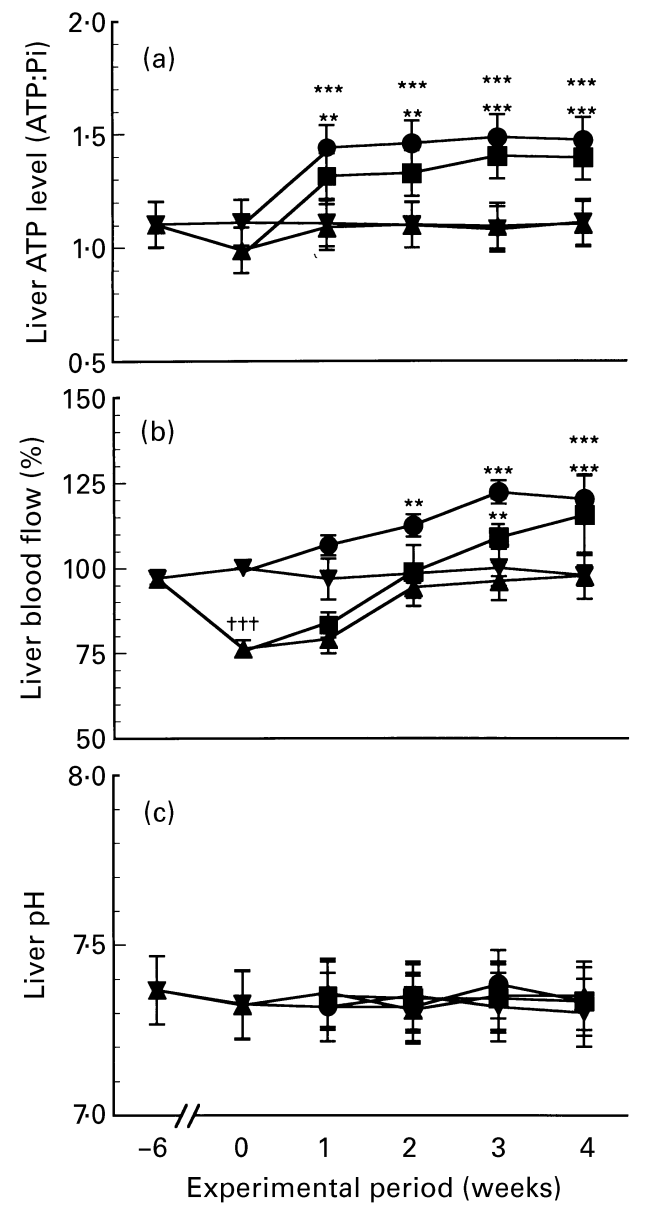

Fig. 2. (a) Hepatic $\beta$-ATP : inorganic phosphate (Pi), (b) liver blood flow and (c) intracellular $\mathrm{pH}$ in the livers of normal $(\boldsymbol{\nabla}, \bullet)$ and anaemic $(\boldsymbol{\Lambda}, \boldsymbol{\square})$ mice receiving vehicle $(\boldsymbol{\nabla}, \mathbf{\Lambda})$ or an extract from Cordyceps sinensis $(200 \mathrm{mg} / \mathrm{kg}$ per d) $(\boldsymbol{\bullet}, \mathbf{\square})$ for 4 weeks. For details of diets, extract and procedures, see Table 1 and pp. 198-199. Blood-flow rates are expressed as a percentage of the mean value for normal controls on day 0 (week 0 ). Values are means for six mice, with their standard errors represented by vertical bars. Mean values were significantly different from those for the corresponding vehicle control group: ${ }^{* \star} P<0.01,{ }^{* *} P<0.001$. Mean value was significantly different from normal control on day $0: 1+\dagger P<0.001$
Prominent peaks for phosphomonoester, $\mathrm{Pi}$, and nucleotide triphosphate (mainly $\gamma$-ATP, $\alpha$-ATP and $\beta$-ATP) were observed. The $\gamma$-ATP and $\alpha$-ATP signals may have included contributions from $\beta$ - and $\alpha$-ADP respectively. The signal corresponding to $\beta$-ATP that had no overlap with other phosphate signals was used to quantify ATP (Takahashi et al. 1990; Manabe et al. 1996). The spectral resolution was sufficient to measure individual peak areas using a digital integration technique. The resolution and the signal: noise ratio of the ${ }^{31} \mathrm{P}$ spectra obtained by the present in vivo method were sufficient for the quantitative evaluation of peak area ratios. These representative figures from both normal and anaemic mice indicated that the peak intensity of the $\beta$-ATP resonance was higher, but the peak intensity of the $\mathrm{Pi}$ resonance was lower in the Cs-extract-treated (Fig. 1(c and d)) than in the vehicle control mice (Fig. 1(a and b)).

Fig. 2(a) shows the time courses of the $\beta$-ATP:Pi peak area ratios obtained from the liver in the Cs-extract-treated and the vehicle control groups of both normal and anaemic mice, as determined by ${ }^{31} \mathrm{P}$ NMR spectroscopy. Slightly lower ATP:Pi values were observed in anaemic mice in comparison with those of normal controls (at 0 week). During the Cs-extract administration period (at 1, 2, 3 and 4 weeks), the ATP:Pi values of the Cs-extract-treated normal mice were significantly higher than those of the vehicle control normal mice $(P<0.001)$. In anaemic groups, the ATP:Pi values were also significantly higher in the Cs-extract-treated than in the vehicle control mice during the Cs-extract administration period (at 1, 2, 3 and 4 weeks; $P<0.01,0 \cdot 01,0.001$ and 0.001 respectively).

The changes in liver blood flow measured by the $\mathrm{D}_{2} \mathrm{O}$ uptake ${ }^{2} \mathrm{H}$ NMR spectroscopy method in both normal and anaemic mice are summarized in Fig. 2(b). Each blood-flow rate was expressed as a percentage of the mean value of the normal control on day 0 ( 0 week). A significantly decreased hepatic blood-flow rate in anaemic mice was noted when compared with that in the normal control mice (at 0 week; $P<0.001$ ). During the Cs-extract administration period (at 2, 3 and 4 weeks), the hepatic blood-flow rates of the Csextract-treated normal mice were significantly higher than those in the vehicle-treated controls $(P<0.01,0.001$ and 0.001 respectively). In anaemic groups, the liver blood-flow rates were also significantly higher in the Cs-extract-treated than in the vehicle control mice (at 3 and 4 weeks; $P<0.01$ and 0.001).

The time courses of changes in the intracellular $\mathrm{pH}$ of the liver (liver $\mathrm{pH}$ ) measured by the chemical shift difference between the Pi and $\alpha$-ATP peaks in the ${ }^{31} \mathrm{P}$ NMR spectra are shown in Fig. 2(c). In both normal and anaemic groups, the liver $\mathrm{pH}$ in the Cs-extract-treated mice was not significantly lower than that in the vehicle-treated controls throughout the experiment.

\section{Discussion}

As described earlier, the fruiting bodies of Cs (parasitic on larvae of Lepidoptera) have long been used in traditional Chinese medicine and have various pharmacological effects on human subjects and animals both in vitro and in vivo (Tsunoo et al. 1995). In a recent study, the extract of cultured Cs was given to male long-distance runners over a 
period of 12 weeks (Hiyoshi et al. 1996). Echocardiography revealed a $6.5 \%$ increase in the ejection fraction and five of seven runners recorded their personal best times during the trial period. The Cs extract evaluated by conventional in vitro pharmacological tests showed non-purinergic and nonadrenergic inhibition of tracheal twitch contractions, and relaxation of persistent contractions of the trachea and the aorta (Tsunoo et al. 1995). Our previous examination of in vivo ${ }^{31} \mathrm{P}$ NMR liver energy levels revealed a consistent increase in high energy state in the liver of normal healthy mice administered Cs extract (Manabe et al. 1996). In the normal mice, moreover, no significant differences were observed in the hepatic intracellular $\mathrm{pH}$ between Cs-extract-treated and control mice, and histopathological evaluation revealed no steatosis, necrosis, inflammation or fibrosis of the liver in Cs-extract-treated mice. In the present study, we investigated the hepatic activation effects of Cs extract on mice with anaemia induced by an $\mathrm{Fe}$-free diet. In general, growing animals require more than $5 \mathrm{mg} \mathrm{Fe} / \mathrm{kg}$ per d from food (Wickramasinghe, 1988). We previously reported that an $\mathrm{Fe}$-free diet induced severe anaemia in rats (Tsuhichita et al. 1991). As summarized in Table 3, severe anaemia was also induced in mice (more than $50 \%$ reductions in packed cell volume and blood haemoglobin level) by feeding on an $\mathrm{Fe}$-free diet for 6 weeks. In the present study, the dietary anaemic mice were given a recovery diet during Cs-extract administration for a period of 4 weeks. Our findings confirmed that the Cs extract had no effect on these haematological variables in either normal or anaemic mice. Moreover, histopathological evaluation demonstrated no pathological changes (steatosis, necrosis, inflammation or fibrosis) in anaemic or control groups during the experiment in the liver sections prepared from either Cs-extract-treated or vehicle control mice. We concluded that the reciprocal administration of Cs extract, at a high dose of $200 \mathrm{mg} / \mathrm{kg}$ per d, has no toxic effect on the liver of either normal or anaemic mice.

The use of in vivo ${ }^{31} \mathrm{P}$ NMR spectroscopy made it possible to overcome the sampling problems associated with conventional biochemical analysis, i.e. HPLC analysis of liver extract, although we measured only free and not total ATP. Moreover, the NMR technique used in the present study is the only non-invasive quantitative method available. Previous studies showed that in vivo serial ${ }^{31} \mathrm{P}$ NMR spectroscopy is a useful technique to detect the changes in liver energy state induced by $\mathrm{CCl}_{4}$ administration in mice (Geoffrion et al. 1988) and rats (Bates et al. 1988; Sandhu et al. 1991), and chronic ethanol feeding in rats (Takahashi et al. 1990; Brauer \& Ling, 1991). Bowers et al. (1992) used ${ }^{31} \mathrm{P}$ NMR to evaluate the liver energy state in rats following orthotopic liver transplantation. The relationship between NMR-visible high-energy phosphate, i.e. ATP, and transplant outcome in the case of liver damage by ischaemia was examined. In vivo ${ }^{31} \mathrm{P}$ NMR spectroscopy was used to analyse the pretransplant liver of donor rats and the post-transplant liver of recipient rats. They confirmed that recovery of NMR-visible high-energy phosphates $20 \mathrm{~min}$ after re-establishment of portal blood flow was a good indicator of transplant outcome in cases of rat liver damage by ischaemia. Yang et al. (1995) also reported that liver energy metabolism assessed by ${ }^{31} \mathrm{P}$-NMR spectroscopy is a good indicator of the viability of graft livers in rats. Recently, Takahashi et al. (1997) evaluated the effects of anaesthetic agents, halothane and isoflurane, on the hepatic phosphor-energetic state by in vivo ${ }^{31} \mathrm{P}$ NMR. They compared the effects of halothane $v$. isoflurane on the phosphor-energetic state, which was evaluated from the changes in $\beta$-ATP: Pi levels, and intracellular $\mathrm{pH}$ of the rat liver using in vivo ${ }^{31} \mathrm{P}$ NMR spectroscopy during and after haemorrhagic shock, and collected consecutive in vivo ${ }^{31} \mathrm{P}$ NMR spectra throughout the study. Their results indicated that intracellular acidosis was more severe in the halothane group and that recovery of $\beta$-ATP : Pi level was better in the isoflurane group. Thus, in vivo ${ }^{31} \mathrm{P}$ NMR spectroscopy, which is the only noninvasive quantitative method available, is useful for consecutive evaluation of both liver energy metabolism and intracellular $\mathrm{pH}$.

In the present study, the ${ }^{31} \mathrm{P}$ NMR spectral resolution and signal: noise ratio were sufficient to measure individual peak areas as shown in Fig. 1. In both normal and anaemic mice, the peak intensity of the $\beta$-ATP resonance was higher, but the peak intensity of the Pi resonance was lower in the Cs-extract-treated mice than in the vehicle-treated controls. During the Cs-extract administration period, the $\beta$-ATP : Pi values of the Cs-extract-treated groups were higher than those in the vehicle-treated controls. Such an increase in the $\beta$-ATP : Pi value strongly suggests that there is a higher energy state in the liver of the Cs-extract-treated mice than in vehicle-treated controls. Interestingly, no significant changes were observed in hepatic intracellular $\mathrm{pH}$, which is determined by the chemical shift difference between the Pi and $\alpha$-ATP peaks in the ${ }^{31} \mathrm{P}$ NMR spectra, in any group, indicating that the Cs extract had no severe hepatotoxicity and maintained normoxic conditions. In general, intracellular acidosis can be induced by hepatotoxic reagents and hypoxic conditions (Desmoulin et al. 1987; Takahashi et al. 1990). Moreover, histopathological findings have revealed that Cs extract does not induce severe hepatotoxic changes in the liver, i.e. no steatosis, necrosis, inflammation or fibrosis.

The mechanism underlying the high hepatic energy state brought about during Cs-extract administration, however, remains unclear. The present study revealed that Cs extract treatment in both normal and anaemic groups increased liver blood flow, as determined by $\mathrm{D}_{2} \mathrm{O}$ uptake- ${ }^{2} \mathrm{H}$ NMR spectroscopy performed according to a modification of the methods of Mattiello et al. (1991) and Zhao et al. (1995), which were suitable for rats. We established a technique appropriate for mice and estimated the mouse liver blood flow by in vivo ${ }^{2} \mathrm{H}$ NMR spectroscopy of $\mathrm{D}_{2} \mathrm{O}$ uptake after intravenous injection of $\mathrm{D}_{2} \mathrm{O}$. Okunieff et al. (1988) and Tozer et al. (1990) reported that hepatic blood flow and energy metabolism are closely linked. In a recent study, Whalen \& Shapiro (1991) measured liver blood flow using a $\mathrm{D}_{2} \mathrm{O}$ washout technique, using ${ }^{2} \mathrm{H}$ NMR and liver concentration of ATP and intracellular $\mathrm{pH}$ determined by ${ }^{31} \mathrm{P}$ NMR techniques in normal rats, and confirmed that liver blood flow rates are linked to liver ATP levels. Zhao et al. (1995) acquired in vivo ${ }^{31} \mathrm{P}$ and ${ }^{2} \mathrm{H}$ NMR spectra to evaluate the blood flow, intracellular $\mathrm{pH}$ and energy metabolism ( $\beta$-ATP: Pi) in mice with implanted tumours and normal livers. They reported that the anaesthetic halothane decreased tumour blood flow, $\beta$-ATP: $\mathrm{Pi}$ value and intracellular $\mathrm{pH}$. In vivo ${ }^{31} \mathrm{P}$ NMR measurements of normal mouse liver 
indicated that halothane had a similar effect in the liver. The induction of ATP synthesis has been suggested to be caused by activated adenine translocase activity and/or mitochondrial respiratory-chain function in the livers of mice receiving Cs extract. The decrease in ATP consumption attributed to depressed Na pump function can theoretically produce a high energy state in the liver (Takahashi et al. 1990). When Na pump function is depressed by toxic agents and hypoxic conditions, severe intracellular acidosis is induced (Desmoulin et al. 1987; Takahashi et al. 1990). However, no such decrease in ATP consumption occurred in the liver of Cs-extract-treated mice, because no severe changes were observed in liver intracellular $\mathrm{pH}$. The hepatotrophic synthetic reagent malotilate, which induces liver hypertrophy, activates hepatic mitochondrial function and increases ATP levels in the liver of normal and partially hepatectomized rats (Niwano et al. 1986). However, Cs extract has no such hypertrophic activity in the liver, and so the mechanism of the increase in hepatic ATP level must be different from that mechanism for the synthetic reagent malotilate. Natural substances also increase hepatic blood flow and ATP levels. For example, Walsh et al. (1993) measured blood flow and high-energy phosphates in control rat livers and in those damaged by ischaemia using in vivo NMR spectroscopy to determine the effects of glucagon on these variables. Ischaemia led to a loss of liver ATP, and then reperfusion showed recovery of ATP. Glucagon treatment before induction of ischaemia accelerated the recovery of hepatic ATP level. Ischaemia-reperfusion decreased hepatic blood flow, and glucagon treatment stimulated liver blood flow in a dose-dependent manner. These results indicated that ischaemia followed by reperfusion leads to a decrease in hepatic blood flow before alterations in ATP and that the response of the liver to glucagon was altered in the reperfused liver. Further investigations to determine the mechanism underlying the high hepatic energy state induced by Cs-extract administration are currently in progress in our laboratory.

The present findings indicate that the traditional Chinese medicine Cs extract increases hepatic blood flow in mice with dietary hypoferric anaemia, a condition associated with reduced blood flow. The Cs extract is considered to relax contractions in the liver blood vessel system and to increase hepatic blood flow, causing liver ATP levels to increase. Such hepatic ATP augmentation may contribute to the acceleration of recovery and improvement of liver function in patients with anaemia. Moreover, the present study showed that in vivo ${ }^{31} \mathrm{P}$ NMR and ${ }^{2} \mathrm{H}$ NMR analyses of the liver, measurement of hepatic energy state and blood flow respectively, were useful tools for evaluation of efficacy of the various nutritional elements, crude drugs, orthodox medicines, traditional herbal remedies and health foods, which improve, recover and/or maintain health. Thus, in vivo assessment methods for energy metabolism and blood flow are useful tools for nutritional sciences.

\section{Acknowledgements}

We thank Drs K Kuramitsu and Y Kuribayashi for excellent technical assistance. This work was supported in part by a Grant-in-Aid to N. M. and H. M. from the Ministry of
Education, Science and Culture, Japan, and by grants to $\mathrm{N}$. M. from the Takeda, Inamori and Itoh Memorial Foundations.

\section{References}

Azuma Y, Manabe N, Kawai F, Kanamori M \& Miyamoto H (1994) Phosphorus-31 nuclear magnetic resonance study of energy metabolism in intact slow- and fast-twitch muscles of rats. Journal of Animal Science 72, 103-108.

Bates TE, Williams SR, Busza AL \& Gadian DG (1988) A ${ }^{31} \mathrm{P}$ nuclear magnetic resonance study in vivo of metabolic abnormalities in rats with acute liver failure. NMR Biomedicine 1, 67-73.

Brauer M \& Ling M (1991) The effect of chronic ethanol consumption on the intact rat liver studied by in vivo ${ }^{31} \mathrm{P} \mathrm{NMR}$ spectroscopy. Magnetic Resonance in Medicine 20, 100-112.

Bowers JL, Teramoto K, Khettery U \& Clouse ME (1992) Phosphorus-31 NMR assessment of orthotopic rat liver transplantation viability: the effect of warm ischemia. Transplantation 54, 604-609.

Chatterjee R, Srinivasan KS \& Maiti PC (1957) Cordyceps sinensis (Berkeley) Saccardo: structure of Cordycepic acid. Journal of the American Pharmaceutical Association 66, 114-118.

Desmoulin F, Canioni P, Crotte C, Gérolami A \& Cozzone PJ (1987) Hepatic metabolism during acute ethanol administration: a phosphorus-31 nuclear magnetic resonance study on the perfused rat liver under normoxic or hypoxic conditions. Hepatology 7, 315-327.

Furuya T, Hirotani M \& Matsuzawa M (1983) $\mathrm{N}^{6}$-(2-Hydroxyethyl) adenosine, a biologically active compound from cultured mycelia of Cordyceps and Isaria species. Phytochemistry 22, 2509-2512.

Geoffrion Y, Rydzy M, Butler KW, Smith ICP \& Jarrell HC (1988) The use of immobilized ferrite to enhance the depth selectivity of in vivo surface coil NMR spectroscopy. NMR Biomedicine 1, 107-112.

Hamada M (1991) Effect of Cordyceps sinensis (Berk.) Sacc. extract upon anti-tumor activity and tumor immunity. Journal of Kanazawa Medical University 16, 46-54.

Hiyoshi T, Akasu F, Yoshisugu M \& Fujiwara M (1996) Supplemental effects of Cordyceps sinensis extract on long distance runners. Japanese Journal of Physical Fitness and Sports Medicine 45, 205-210.

Japanese Animal Care Committee (1981) Guide for the care and use of laboratory animals. Experimental Animal 30, 173-178.

Malloy CR, Cunningham CC \& Radda GK (1986) The metabolic state of the rat liver in vivo measured by ${ }^{31} \mathrm{P}-\mathrm{NMR}$ spectroscopy. Biochimica et Biophysica Acta 885, 1-11.

Manabe N, Sugimoto M, Azuma Y, Taketomo N, Yamashita A, Tsuboi H, Tsunoo A, Kinjo N, Nian-Lai H \& Miyamoto H (1996) Effect of the mycelial extract of cultured Cordyceps sinensis on in vivo hepatic energy metabolism in the mouse. Japanese Journal of Pharmacology 70, 85-88.

Mattiello J \& Evelhoch JL (1991) Relative volume-average murine tumor BF measurement via deuterium nuclear magnetic resonance spectroscopy. Magnetic Resonance in Medicine 18, 320334.

Niwano Y, Konaka S, Uchida M \& Sugimoto T (1986) Activation of mitochondrial functions by malotilate in relation to accelerated liver regeneration in partial hepatectomized rats. Japanese Journal of Pharmacology 42, 525-529.

Okunieff P, Kallinowski F, Vaupel P \& Neuringer LJ (1988) Effects of hydralazine-induced vasodilation on the energy metabolism of murine tumors studied by in vivo 31-nuclear magnetic resonance spectroscopy. Journal of the National Cancer Institute 80, 745-750.

Sandhu GS, Gonnella NC, Kapeghian JK, Plocinski AK, Plutchok 
J \& Schlosser MJ (1991) Evaluation of ${ }^{31}$ P NMR spectroscopy as an indicator of chemically induced hepatic toxicity in the rat: comparison with serum enzyme levels and pathology. NMR Biomedicine 4, 12-15.

Takahashi H, Geoffrion Y, Butler KW \& French SW (1990) In vivo hepatic energy metabolism during the progression of alcoholic liver diseases: a noninvasive ${ }^{31} \mathrm{P}$ nuclear magnetic resonance study in rats. Hepatology 11, 65-73.

Takahashi K, Shigemori S, Nosaka S, Morikawa S \& Inubushi T (1997) The effects of halothane and isoflurane on the phosphorenergetic state of the liver during hemorrhagic shock in rats: an in vivo ${ }^{31} \mathrm{P}$ nuclear magnetic resonance spectroscopic study. Anesthesia and Analgesia 85, 347-352.

Tozer GM, Maxwell RJ, Griffiths JR \& Pham P (1990) Modification of the ${ }^{31} \mathrm{P}$ magnetic resonance spectra of a rat tumour using vasodilators and its relationship to hypotension. British Journal of Cancer 62, 553-560.

Tsuhichita H, Kobayashi A, Kojima T, Kuwata T, Noguchi T, Koto K \& Takahashi T (1991) Bioavailability of iron from ferric pyrophosphate. Journal of Agricultural and Food Chemistry 39, 316-321.

Tsunoo A, Takemoto N \& Kamijo M (1995) Pharmacological effects of the mycelial extract of cultured Cordyceps sinensis on airways and aortae of the rat. In Science and Cultivation of Edible Fungi, pp. 425-431 [YJ Elliott, editor]. Rotterdam: Balkema.

Walsh TR, Detre JA, Koretsky AP, Simplaceanu E, Halow JM, Rao P, Makowka L \& Ho C (1993) Response of normal and reperfused livers to glucagon stimulation: NMR detection of BF and highenergy phosphates. Biochimica et Biophysica Acta 1181, 7-14.

Whalen M \& Shapiro JI (1991) Controlled ventilation during NMR spectroscopic studies: hemodynamic and biochemical consequences. Magnetic Resonance Imaging 9, 229-234.

Wickramasinghe SN (1988) Nutritional anaemia. Clinical and Laboratory Haematology 10, 117-134.

Yang M, Shimada H, Kobayashi T, Niimoto S \& Nakagawara G (1995) Predicting the viability of graft livers in rats through a rapid and sensitive metabolic indicator assessed by ${ }^{31} \mathrm{P}-\mathrm{NMR}$ spectroscopy. Surgery Today 25, 711-716.

Yoshida J, Takamura S, Suzuki S \& Koshimura S (1992) Potentiating effect of an extract of Cordyceps sinensis (Berk.) Sacc. on cytostatic activity of mouse effector cells against tumor cells. Journal of Kanazawa Medical University 17, 330-335.

Zhao M, Fortan LG \& Evelhoch JL (1995) The effects of isoflurane and halothane on blood flow and ${ }^{31} \mathrm{P}$ NMR spectra in murine RIF-1 tumors. Magnetic Resonance in Medicine 33, 610-618. 